\title{
Nerve Regeneration and Stem Cells
}

\author{
Kamal Seyed-Forootan ${ }^{1}$, Hamid Karimi*2, Ali-Akbar Jafarian ${ }^{3}$, Nazilla-Sadat Seyed-Forootan ${ }^{4}$ Farzad \\ Kargarzadeh Ravari ${ }^{5}$ and Ali-Mohammad Karimi ${ }^{6}$ \\ ${ }^{1}$ Associate Professor of Plastic and Reconstructive Surgery, Faculty of Medicine, Iran University of Medical Sciences, Iran \\ ${ }^{2}$ Professor of Plastic and Reconstructive Surgery, Faculty of Medicine, Iran University of Medical Sciences, Iran
}

${ }^{3}$ Associate Professor of Anesthesiology, Faculty of Medicine, Iran University of Medical Sciences, Iran

${ }^{4}$ Medical school, case western reserve university, USA

${ }^{5}$ Orthopedic surgeon, Private practice, UAE, Iran

${ }^{6}$ Iran University of Medical School, Tehran, Iran

*Corresponding author: Hamid Karimi, Professor of Plastic and Reconstructive Surgery, Iran University of Medical Sciences, ehran, Iran

\begin{tabular}{ll}
\hline ARTICLE INFO & ABSTRACT \\
$\begin{array}{l}\text { Received: May 22, } 2019 \\
\text { Published: }\end{array}$ & $\begin{array}{c}\text { Background: Peripheral nerve trauma results in functional loss in the innervated } \\
\text { organ. Recovery without surgical intervention is seldom successful. Many surgical } \\
\text { techniques can be used for repair in experimental models. }\end{array}$
\end{tabular}

Citation: Kamal Seyed-F, Hamid K, AliAkbar J, Nazilla-Sadat Seyed-F, Farzad Kargarzadeh R, Ali-Mohammad K. Nerve Regeneration and Stem Cells. Biomed J Sci \& Tech Res 18(3)-2019. BJSTR. MS.ID.003147.

Keywords: Stem Cells; Pluripotential; Regeneration; Nerve; Trauma

Objective: The authors investigated the source and delivery method of stem cells, their outcomes, and whether stem cells will be differentiated in the injured nerve and whether they improve the regenerative process.

Materials and Methods: The following key terms were used: nervous regeneration, nerve regeneration, facial nerve regeneration, stem cells, embryonic stem cells, fetal stem cells, adult stem cells, peripheral nerve, peripheral nerve trauma, and peripheral nerve traumatism. The inclusion criteria were the experimental studies that applied stem cell therapy and tissue engineering for nerve repair.

Results: Out of 197 studies, 52 studies meeting the inclusion criteria were reviewed. Different sources of stem and precursor cells were noticed (bone marrow mesenchymal stem cells, adipose-derived stem cells, dental pulp cells, umbilical cord, and neural stem cells) for their potential application in the patients with peripheral nerve injuries. Different material conduits (vases, collagen, and polyglycolic acid) were used as bridges between the two nerve endings. Immunochemistry and electrophysiology were used for analyzing regenerative effects. Although recent studies have shown that stem cells can act as a promising bridge for nerve repair, considerable optimization of these therapies will be required for their usage in a clinical setting.

Conclusion: The use of stem cells derived from different sources presents promising results for nerve regeneration and effective neural and functional results. The best choices are BMSC and ADSC. The use of conduit also help and maximize the nerve repair, and in this way induce better myelination and axonal growth of peripheral nerves. [Patent CA2958398A1, Patent WO2016023130A1, Patent EP1685832B1].

\section{Introduction}

Nerve traumas are very common in the world and complete disruption of the nerve trunks without treatment, would result in partial regeneration and repair, partial or total loss of function $[1,2]$. One of the treatments for these traumas, is direct repair of disrupted nerve, which is sometimes possible. In most of the cases, it needs urgent repair, normally before 6-12 hours after the accident. Other treatment is nerve graft, but it may not diagnosed in proper time, or is not possible, sometimes there is lack of enough donor nerve graft available and sometimes it would not result in complete healing because of the nature of trauma and nature of function of that particular nerve [3]. 
Currently new modality for treatment of these traumas is using stem cells. We know that pluripotential stem cell from bone marrow, adipose tissue, skin, dental pulp, umbilical cord or from nerve trunks can differentiate into the Schwann cells and nerve cells with axons. It could help in regeneration of the missing nerves. The function of these cells is supposed to be a combination of selfrenewal function, production and release of many growth factors, preparing the environment for nerve growth and to provide a closed space for axons to grow [4-11]. The difference between Central Nervous System (CNS) and Peripheral Nervous System (PNS) is the presence of Schwann cells in PNS.

In this regard the PNS with the help of Schwann cells can grow and regenerate more properly and effectively $[2,12]$. Harvesting the Schwann cells, culturing and using them in proper time is not easy and we may not use them in the right and proper time after the trauma (delay in treatment). So, the other way is to use stem cells. Stem cells from bone marrow, adipose tissue, skin, dental pulp, umbilical cord and nerve tissue has been used for this purpose. The best, easiest (and cheapest) cells for cell culture and differentiation into the Schwann cells of nerve cells and axons are Bone Marrow Mesenchymal Stem Cells (BMSC) [1-3]. In this review article we are going to review the most recent and the most important researches about stem cells and usage of them in nerve repair.

\section{Materials and Methods}

With using two search engines, Pubmed and Embase. Following key terms were used: stem cells, embryonic stem cells, fetal stem cells, nervous regeneration, nerve regeneration, peripheral nerve regeneration, central nervous system regeneration; nerve repair; adult stem cells, Adipose derived stem cells; skin stem cells; nerve stem cells; facial nerve, dental pulp stem cells, and nerve trauma. The search was restricted to experimental studies that used stem cell and tissue engineering for nerve repair after trauma. All relevant papers were chosen and their data were used for the present manuscript. This review article has been written on the base of these researches.

Out of these studies, 13 were about using stem cells in nerve repair, 30 were about using BMSC, 9 were about ADSC, 17 were about MSC, 2 were about HSC, one was about skin SC, 12 were about NSC, 5 were discussed other stem cells origins. There were some studies (5 studies) about using growth factors and neurotrophic factors.

\section{Results}

We found 197 papers and some of them were not relevant, 52 papers were selected for our study. All the 52 papers were studies which meet the inclusion criteria. Different sources of stem and precursor cells were explored (bone marrow mesenchymal stem cells, adipose-derived stem cells, skin stem cells, dental pulp cells, umbilical cord cells and neural stem cells) for their potential application in the repair of nerve injuries or traumas. Different material conduits (veins, collagen, synthetic conduits, and polyglycolic acid) were used as bridges. Immunochemistry and electrophysiology were the principal methods for analyzing.

Regeneration results of the treatment. Recent studies have shown that stem cells can act as a promising bridge for nerve repair, considerable optimization of these therapies will be needed for them to be used in a clinical setting. Out of these studies, 13 were about using stem cells in nerve repair, 30 were about using BMSC, 9 were about ADSC, 17 were about MSC, 2 were about HSC, 2 were about skin SC, 12 were about NSC, 5 were discussed other stem cells origins. There were some studies ( 5 studies) about using growth factors and neurotrophic factors.

\section{Discussion}

For repairing the nerve injuries, we have three options available; direct nerve suturing, nerve graft and stem cell or Schwann cell repair $[1,3]$. Although some of the results of the first two options are acceptable, but none of them are excellent and always we would have some remaining defects in the nerve function.

\section{Schwann Cells}

According to numerous studies, using Schwann cells has a very good result in most of the reports. But their harvesting would result to injury to the other nerves. Time for culture of Schwann cells is somehow long, reproduction of these cells is very long and we cannot re-produce enough Schwann cells in proper time [4].

\section{Stem Cells}

The next option is to use precursor stem cells, many studies promoting using the stem cells, culture them and use them after differentiation into nerve cells or Schwann cells [4,5,13-16]. According to studies and literature, stem cells can differentiate into the special cells that are needed for the repair of the defective tissue, can produce growth factors for growth of these cells [4,17-19], can produce regenerative factors, bioactive molecules [14], special growth factors [14], regulating molecules [20], trophic molecules [2,11,19,21-25], special extracellular matrix molecules [21], cytokines for differentiation of the stem cells into proper cells $[4,18,19,26,27]$, promoting re-myelination [4,21], Structural support [11], increase in plasticity [11], reduction in retrograde degeneration [11], they are neuro-protective [19,28], they modulate the bed tissues [22], can modulate the immune system and produce proper environment for the regeneration of nerves $[5,11,19,21,29,30]$. Some of the cells would differentiate into endothelial cells to re-vascularize the tissue or have neovascularization effects [31-33]. These cells can reverse and remodel the injured tissue [34]. In this way they have neuro-regenerative and neuro-protective potentials $[19,28]$.

\section{Embryonic Cells}

The embryonic cells and fetal cells are multi-potential cells that can be used for this issue, but usage of them has ethical problems and in most of the centers their usage is prohibited $[6,7,35]$. 
Therefore, the best option is adult stem cells. Adult stem cells can umbilical cord, skin, dental pulp and nerve tissues [1,3,36,37] be harvested from Bone Marrow (BMSC), Adipose Tissues (ADSC), (Table 1).

Table 1: Comparison of different stem cells in regeneration of nerve tissue.

\begin{tabular}{|c|c|c|c|}
\hline Type of stem cells & Advantages & Disadvantages & References \\
\hline BMSC & $\begin{array}{c}\text {-Easy to harvest } \\
\text {-Expandable } \\
\text {-Better differentiation to the nerves } \\
\text { - highly proliferative } \\
\text {-neurotrophic effect } \\
\text {-neurogenesis }\end{array}$ & -harvest by inward admission & {$[1,4,5,6,11,14,20,23,25,32,38]$} \\
\hline ADSC & $\begin{array}{c}\text {-Easy to harvest } \\
\text {-Expandable } \\
\text { - good colonization effects } \\
\text { - no functional loss } \\
\text {-Abundant amount } \\
\text {-fast culture }\end{array}$ & $\begin{array}{l}\text { - Not possible in thin } \\
\text { patients }\end{array}$ & {$[2,31,37,39]$} \\
\hline Neural stem cells & -good differentiation to the nerve tissue & $\begin{array}{l}\text {-trauma to normalnerves } \\
\text {-difficult to harvest }\end{array}$ & [1] \\
\hline Olfactory ensheating cells & $\begin{array}{l}\text { - neurotrophic and neuroprotective } \\
\text { effects } \\
\text {-myelinization }\end{array}$ & $\begin{array}{l}\text {-very difficult to harvest } \\
\text {-Donor deficit }\end{array}$ & {$[19,26]$} \\
\hline Dental pulp progenitor cells & $\begin{array}{l}\text { - dedifferentiate into Schwann cells and } \\
\text { nerve cells }\end{array}$ & $\begin{array}{l}\text {-difficult to harvest } \\
\text {-Donor deficit }\end{array}$ & {$[3,31]$} \\
\hline Small embryonic stem cells & - potential stem cells for all tissues & $\begin{array}{l}\text { - difficult to harvest } \\
\text { - very few in number }\end{array}$ & {$[19,26,30]$} \\
\hline Epiblast stem cells & - pluripotential potential & $\begin{array}{l}\text { - difficult to harvest } \\
\text { - very few in number }\end{array}$ & [19] \\
\hline Umbilical stem cells & $\begin{array}{l}\text { - can produce the Schwann cells, neural } \\
\text { cells and axons }\end{array}$ & $\begin{array}{l}\text {-No source if it is not banked } \\
\text { earlier }\end{array}$ & Umbilical stem cells \\
\hline - if used earlier, it is not expandable & 5,7 & & - if used earlier, it is not expandable \\
\hline
\end{tabular}

\section{Bone Marrow Stem Cells}

There many Studies about using BMSC for Nerve Repair: BMSC are pluripotential and can be easily harvested, they are highly proliferative and can differentiate into other lineage of the tissues, for example from mesoderm into ectoderm derive tissues. They also have neurotrophic effects for the injured nerves. It has been shown that Mesenchymal Stem Cells (MSC), specially BMSC are best candidate for regeneration of the nerve tissues. They can easily differentiate into Schwann cells and axons $[1,4,5]$. They have low immunogenicity and have proper immunomodulation effects $[5,11]$. Most of the studies about repair with stem cells are based on BMSC. The BMSCs have been used for bone fusion, treatment of cartilage degeneration, spinal cord repair and degeneration of discs, bone defects, non-unions and osteoblast reproduction [6,14,20,32]. They have also been used for reproduction of myocardial cells, kidney, liver and for insulin-producing cells of pancreas $[6,14,38]$. It has been postulated that BM stem cells can give neurotrophic factor gene (s) to the genome of the neurons [23]. So this is a kind of gene delivery and can induce neurogenesis [25].

\section{Adipose-Derived Stem Cells}

The ADSCs are numerous and can be easily harvested from the excess fat tissues in the body. Adipose-Derived Stem Cells (ADSC) can be harvested very easily, are expandable, and can be easily differentiated into Schwann cells. They have good nerve colonization effects. The donor sites are expandable and there would be no functional loss after harvesting the fat tissue. The amount of fat stem cells in the adipose tissue is abundant. Harvesting is easy, fast and culturing of the cells is also fast $[2,31,37,39]$. They have very good results in nerve repair with good functional results.

\section{Neural Stem Cells}

Neural stem cells are other option. These cells are very capable in re-producing the nerve and neural tissue, but they are difficult to harvest, the amount of harvest is not high, and it always results 
in damage to the donor nerves. So, in most of the trauma cases it cannot be used [1]. But the results are very good, and the surgeon can rely on the results with NSCs.

\section{Olfactory Ensheating Cells}

Olfactory ensheating cells are some sort of Schwann cells that are present both in PNS and CNS. They have neurotrophic and neuroprotective effects. They can secret cytokines. They can be used in regeneration of the nerves. These cells can bridge the defect and provide a good environment for nerve growth. Also, they can induce myelinization of the axons. So, they are very powerful in nerve repair $[19,26]$.

\section{Dental Pulp Progenitor Cells}

Dental pulp progenitor cells can also be used for cell culture and treatment of nerve injuries. These are MSC and dedifferentiate into Schwann cells and nerve cells. It is said that they have characteristic of MSCs so can be used for repair of injured nerves $[3,31]$. Harvesting is easy and with abundant stem cells.

\section{Small Embryonic-like Stem Cells}

Very small embryonic-like stem cells are the cells that are normally found in bone marrow and they can migrate to the peripheral blood. They are potential stem cells for all part of the human body. They are also present in the brain. These cells are very few and can go to any part of the body and begin the tissue repair $[19,26,30]$. The studies about these cells are few. And it needs more researches to confirm its results.

\section{Epiblast/Germ Line-Derived Stem Cells}

Epiblast/germ line-derived stem cells are the cells that have pluripotential potential and can differentiate into many lines of cells and start to regenerate the whole organ [19].

\section{Umbilical Cord Stem Cells}

Umbilical cord stem cells (endothelial progenitor cells, hematopoietic stem cells) are a kind of MSCs and can produce the Schwann cells, neural cells and axons. Fortunately, their use has not any ethical issue [5,7]. Their results are very promising and good results have been reported.

\section{Skin Stem Cells}

Skin-derived precursor cells also have been used for wound healing and skin defects. They can also be used for regeneration of the nerves. The function of these progenitor cells is that they work according to the cell differentiation, type of delivery, number of the injected cells and differentiation into other progenitor cells [40].

\section{Conduits}

For having complete effects of stem cells during the repair of neural tissues, some authors recommend using conduits, fibrin glue, immune-modulator drugs, scaffolds, biomaterials and rehabilitation, functional electrical stimulation, and physiotherapy $[2,3,11,14,32,41-43]$. Four mechanism has been postulated for the action of stem cells; resident stem cells, circulating stem cells, transient dedifferentiation of local paranchyma and neuroneogenesis $[23,25,44]$. With these mechanisms the stem cells can have a good to excellent results for nerve repair

Although recent studies have shown that stem cells can act as a promising bridge for nerve repair, considerable optimization of these therapies will be needed for them to be used in a clinical setting. Limitations of our study were that only papers with English language have been selected. The most of studies have been done on animals and human researches are few.

\section{Current and Future Development}

Currently most of investigations are focused on the nerve promoter or stem cell promoters. These compounds can help in differentiation of stem cells into neuroblast and also can help in regeneration of the injured nerves. The resulted nerves are much thicker after the regeneration with much more axons and a better function. With the invent of these growth factors, we can have a rather complete recovery after nerve injury. Some examples are promoters of growth factors that are added to the conduits for better nerve regeneration. Patent CA2958398A1, Patent W02016023130A1, Patent EP1685832B1 [45-47].

\section{Conclusion}

Stem cells have very high potentials in repair and regeneration of neural tissues. BMSC and ADSC are the best options. They can have complete healing effects by adding functional cells, differentiation to neural tissue, producing proper environment, secreting cytokines, trophic factors and immunomodulators. The best choice of stem cells for neural regeneration is BMSC. They can be easily harvested, are highly proliferative and have neurotrophic effects.

\section{References}

1. Shi G, Y Hu (2015) Research progress in seeding cells of peripheral nerve. Sheng Wu Yi Xue Gong Cheng Xue Za Zhi 32(2): 470-474.

2. Zack-Williams SD, Butler PE, Kalaskar DM (2015) Current progress in use of adipose derived stem cells in peripheral nerve regeneration. World J Stem Cells 7(1): 51-64.

3. Euler de Souza Lucena E, Guzen FP, Lopes de Paiva Cavalcanti JR, Galvão Barboza CA, Silva do Nascimento E, et al. (2014) Experimental considerations concerning the use of stem cells and tissue engineering for facial nerve regeneration: A systematic review. J Oral Maxillofac Surg 72(5): 1001-1012.

4. Wakao S, Matsuse D, Dezawa M (2014) Mesenchymal stem cells as a source of Schwann cells: their anticipated use in peripheral nerve regeneration. Cells Tissues Organs 200(1): 31-41.

5. Frausin S, Viventi S, Verga Falzacappa L, Quattromani MJ, Leanza G, et al. (2015) Wharton's jelly derived mesenchymal stromal cells: Biological properties, induction of neuronal phenotype and current applications in neurodegeneration research. Acta Histochem 117(4-5): 329-338.

6. Joshua Schroeder, Janina Kueper, Kaplan Leon, Meir Liebergall (2015) Stem cells for spine surgery. World J Stem Cells 7(1): 186- 194.

7. Passier R, Mummery C (2003) Origin and use of embryonic and adult stem cells in differentiation and tissue repair. Cardiovasc Res 58(2): 324 335 . 
8. Kicic A, Shen W, Rakoczy PE (2001) The potential of marrow stromal cells in stem cell therapy. Eye (Lond) 15(Pt 6): 695-707.

9. Fischer I (2000) Candidate cells for transplantation into the injured CNS. Prog Brain Res 128: 253-257.

10. Compston A, Zajicek J, Sussman J, Webb A, Hall G, et al. (1997) Glial lineages and myelination in the central nervous system. J Anat $190(\mathrm{Pt}$ 2): 161-200.

11. Ruff CA, Wilcox JT, Fehlings MG (2012) Cell-based transplantation strategies to promote plasticity following spinal cord injury. Exp Neurol 235(1): 78-90.

12. Cai S, Shea GK, Tsui AY, Chan YS, Shum DK (2011) Derivation of clinically applicable schwann cells from bone marrow stromal cells for neural repair and regeneration. CNS Neurol Disord Drug Targets 10(4): 500508.

13. Oliveira JT, Mostacada K, de Lima S, Martinez AM (2013) Bone marrow mesenchymal stem cell transplantation for improving nerve regeneration. Int Rev Neurobiol 108: 59-77.

14. Salamon A, Toldy E, Nagy L, Lőcsei Z (2012) The role of adult bone marrow derived mesenchymal stem cells in the repair of tissue injuries. Orv Hetil 153(46): 1807-1815.

15. Kamal Seyed Forootan, Siamak Farokh Forghani, Seyed Pezhman Madani, Hamid Karimi Estahbanati, Nazilla Sadat Seyed Forootan (2015) Laser therapy after repair of the distal half of the median nerve: A comparative study. Trauma Mon 20(2): e23816.

16. Kamal Seyed Foroutan, Ali Khodarahmi, Hootan Alavi, Sepehr Pedram, Mohamad Reza Baghaban Eslaminejad, et al. (2015) Bone marrow mesenchymal stem cell and vein conduit on sciatic nerve repair in rats. Trauma Mon 20(1): e23325.

17. Brandacher G, Grahammer J, Sucher R, Lee WP (2012) Animal models for basic and translational research in reconstructive transplantation. Birth Defects Res C Embryo Today 96(1): 39-50.

18. Scuteri A, Miloso M, Foudah D, Orciani M, Cavaletti G, et al. (2011) Mesenchymal stem cells neuronal differentiation ability: A rea perspective for nervous system repair? Curr Stem Cell Res Ther 6(2): 82-92.

19. Radtke C, Wewetzer K, Reimers K, Vogt PM (2011) Transplantation of olfactory ensheathing cells as adjunct cell therapy for peripheral nerve injury. Cell Transplant 20(2): 145-152.

20. Chen BY, Wang X, Chen LW, Luo ZJ (2012) Molecular targeting regulation of proliferation and differentiation of the bone marrow-derived mesenchymal stem cells or mesenchymal stromal cells. Curr Drug Targets 13(4): 561-571.

21. Dadon-Nachum M, Melamed E, Offen D (2011) Stem cells treatment for sciatic nerve injury. Expert Opin Biol Ther 11(12): 1591-1597.

22. Kitada M, Dezawa M (2009) Induction system of neural and muscle lineage cells from bone marrow stromal cells: A new strategy for tissue reconstruction in degenerative diseases. Histol Histopathol 24(5): 631642.

23. Korochkin LI, Revishchin AV, Okhotin VE (2006) Neural stem cells and their role in recovery processes in the nervous system. Neurosci Behav Physiol 36(5): 499-512.

24. Korochkin, LI, Revishchin AV, Okhotin VE (2005) Neural stem cells and their significance in regeneration processes in the nervous system. Morfologiia 127(3): 7-16.

25. Corti S, Locatelli F, Strazzer S, Guglieri M, Comi GP (2003) Neurona generation from somatic stem cells: current knowledge and perspectives on the treatment of acquired and degenerative central nervous system disorders. Curr Gene Ther 3(3): 247-272.
26. Radtke C, Kocsis JD, Vogt PM (2029) Chapter 22: Transplantation of olfactory ensheathing cells for peripheral nerve regeneration. Int Rev Neurobiol 87: 405-415.

27. Claps CM, Corcoran KE, Cho KJ, Rameshwar P (2005) Stromal derived growth factor-1alpha as a beacon for stem cell homing in development and injury. Curr Neurovasc Res 2(4): 319-329.

28. Moraleda JM, Blanquer M, Bleda P, Iniesta P, Ruiz F, et al. (2016) Adult stem cell therapy: Dream or reality? Transpl Immunol 17(1): 74-77.

29. Stocum DL (2005) Stem cells in CNS and cardiac regeneration. Adv Biochem Eng Biotechnol 93: 135-159.

30. Kocsis JD, Akiyama Y, Radtke C (2004) Neural precursors as a cell source to repair the demyelinated spinal cord. J Neurotrauma 21(4): 441-449.

31. Tobita M, Mizuno H (2013) Adipose-derived stem cells and periodontal tissue engineering. Int J Oral Maxillofac Implants 28(6): e487-e493.

32. Wu X, Ren J, Li J (2012) Fibrin glue as the cell-delivery vehicle for mesenchymal stromal cells in regenerative medicine. Cytotherapy 14(5): 555-562.

33. Ratajczak J, Zuba-Surma E, Paczkowska E, Kucia M, Nowacki P, et al. (2011) Stem cells for neural regeneration--a potential application of very small embryonic-like stem cells. J Physiol Pharmacol 62(1): 3-12.

34. Guan K, Hasenfuss G (2007) Do stem cells in the heart truly differentiate into cardiomyocytes? J Mol Cell Cardiol 43(4): 377-387.

35. Enzmann GU, Benton RL, Talbott JF, Cao Q, Whittemore SR (2006) Functional considerations of stem cell transplantation therapy for spinal cord repair. J Neurotrauma 23(3-4): 479-495.

36. Totey S, Pal R (2009) Adult stem cells: A clinical update. J Stem Cells 4(2): 105-121.

37. Valdés Chavarri M, Pascual Figal D, Prósper Cardoso F, Moreno Montañés J, García Olmos D, et al. (2005) Regenerative medicine with adult stem cells. Rev Clin Esp 205(11): 556-564.

38. Wen Z, Zheng S, Zhou C, Wang J, Wang T (2011) Repair mechanisms of bone marrow mesenchymal stem cells in myocardial infarction. J Cell Mol Med 15(5): 1032-1043.

39. Eun SC (2014) Stem cell and research in plastic surgery. J Korean Med Sci 29 Suppl 3: S167-S169.

40. Walsh S, Midha R (2009) Practical considerations concerning the use of stem cells for peripheral nerve repair. Neurosurg Focus 26(2): E2.

41. Jones DG, Anderson ER, Galvin KA (2003) Spinal cord regeneration: Moving tentatively towards new perspectives. Neuro Rehabilitation 18(4): 339-351.

42. Gu X (2010) Research progress of tissue engineered nerve grafts. Zhongguo Xiu Fu Chong Jian Wai Ke Za Zhi 24(7): 860-863.

43. Lim PA, Tow AM (2007) Recovery and regeneration after spinal cord injury: A review and summary of recent literature. Ann Acad Med Singapore 36(1): 49-57.

44. Iarygin KN (2008) The role of resident and circulating stem cells in physiological and reparative regeneration. Patol Fiziol Eksp Ter 2008(1): $2-8$

45. NA Latifi, H Karimi (2017)Acute electrical injury: A systematic review. Journal of Acute Disease 6(3): 93-96.

46. NA Latifi, H Karimi (2017) Why burn patients are referred? Burns 43(3): 619-623.

47. NA Latifi, H Karimi, SA Motevalian, M Momeni (2017) Economical burden of burn injuries in a developing country. Journal of Burn Care \& Research 38(6): e900-e905. 
48. NA Latifi, H Karimi (2018) Correlation of occurrence of infection in Burn patients. Suicide 107: 62

49. Lim PA, AM Tow (2007) Recovery and regeneration after spinal cord injury: a review and summary of recent literature. Ann Acad Med Singapore 36(1): 49-57.

50. Iarygin KN (2008) The role of resident and circulating stem cells in physiological and reparative regeneration. Patol Fiziol Eksp Ter 2008(1): 2-8.

\section{ISSN: 2574-1241}

DOI: 10.26717/BJSTR.2019.18.003147

Hamid Karimi. Biomed J Sci \& Tech Res

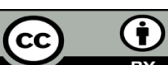

This work is licensed under Creative Commons Attribution 4.0 License

Submission Link: https://biomedres.us/submit-manuscript.php
51. Karimi H, Soudmand A, Orouji Z, Taghiabadi E, Mousavi SJ (2004) Burn wound healing with injection of adipose-derived stem cells: a mouse model study. Ann Burns Fire Disasters 27(1): 44-49.

\section{Patent CA2958398A1}

53. Patent WO2016023130A1

54. Patent EP1685832B1

$\begin{array}{ll}\text { BIOMEDICAL } & \text { Assets of Publishing with us } \\ \text { RESEARCHES } & \text { - Global archiving of articles } \\ & \text { - Immediate, unrestricted online access } \\ & \text { - Rigorous Peer Review Process } \\ \end{array}$

